\title{
Review Article: Comparative Political Science and the Study of Education
}

\author{
MARIUS R. BUSEMEYER AND CHRISTINE TRAMPUSCH*
}

The study of education has long been a neglected subject in political science. Recently, however, scholarly interest in the field has been increasing rapidly. This review essay introduces the general readership to this burgeoning literature with a particular focus on work in comparative public policy and political economy. Particular topics discussed are the historical and political foundations of contemporary education systems, the political and institutional determinants of education policies, the internationalization and Europeanization of education, the political economy of skill formation in varieties of capitalism and the effects of education policies. The article also introduces scholarship in related disciplines such as economics, sociology and comparative education sciences, and points out avenues for future interdisciplinary dialogue between political science and these disciplines.

More than twenty-five years ago, the prominent educational scholar Burton R. Clark began his seminal contribution to the governance of higher education institutions with a lament. After noting an upsurge of interest in the study of education at that time, he complained that scholars of the social sciences remained interested in education 'too briefly' and soon wandered back to their respective home turf, allowing:

organizational theorists to gaze awhile upon the odd ways of universities and then return to the business firm; political scientists to assemble some essays on government and higher education and then go back to traditional political institutions; economists to measure some inputs and outputs and speculate on benefits and costs and then find other topics for their tools; sociologists to absorb education in the study of stratification and forget about the rest. (Clark 1983: 1)

With hindsight, it can be claimed that Clark's apprehension was probably too pessimistic if one considers the development of disciplines such as educational sociology, the comparative education sciences or the economics of education (see Stevens et al. 2008; Rouse \& Barrow 2009; Bray et al. 2007 for respective overviews). The exception, however, is political science in general, and the field of comparative political science in particular. Here, the study of education has long been a 'neglected field' (Jakobi et al. 2009a), especially when compared to comparative welfare state research (Iversen \& Stephens 2008). This review article will show, nevertheless, that this long-neglected field is quickly gaining the attention of scholars. The past twenty-five years have seen an upsurge in political science work on issues such as the partisan politics of education reform, the

* Department of Political Science and Management, University of Konstanz (email: Marius.Busemeyer@unikonstanz.de); and Department of Political Science, University of Bern, respectively. The authors are indebted to the participants in our education workshop held in 2009 at the European Consortium for Political Research Joint Sessions in Lisbon for insights gained through discussions with them. They would also like to thank Carsten Jensen, Moira Nelson and Rita Nikolai, as well as the referees and Editors of this Journal for their valuable comments. Finally, Anne Burian provided excellent research assistance. 
comparative political economy of skill formation, institutional complementarities between education and the welfare state, and the internationalization of education. The goal of this article is to introduce the general readership to this burgeoning field of scholarship and to document how the recent contributions relate to and build on previous work. ${ }^{1}$

Even in an introduction to an under-researched field, imposing certain limitations on the breadth of the perspective is unavoidable - in particular, in the study of education, where neighbouring disciplines have produced such a wealth of scholarship. Therefore, we have applied the following criteria of selection.

First, we focus on work that is broadly comparative. Although in specific instances, single case studies can be situated in a comparative context, we do not discuss at length the significant number of studies that are mostly concerned with the description of historical developments in education in certain countries, unless these studies are placed in a comparative framework and specifically address questions of mainstream political science theories.

Secondly, we are more interested in scholarship that treats education policy as the output of concern and that identifies the political and institutional factors that explain this output. We are also interested in the effects of education policies on outcomes such as stratification or competitiveness. However, we review studies in this strand of research relatively selectively by analysing how far findings on the effects of education policy may be helpful in understanding the politics of education. We believe that policy outcomes decisively influence the formation of policy preferences and political coalitions. This perspective expands that of Heidenheimer, who stated that the purpose of political science work on education, in contrast to the contributions of sociologists and economists, is 'to complement their efforts by analysing how differences in political institutions and processes have contributed to creating and maintaining some distinctive policy emphases' (Heidenheimer 1997: 3-4). On the basis of our review, we would add that these differences in institutions and processes can only be understood if we also analyse the outcomes of education policy as such.

Thirdly, we review literature concerned with studying the politics of education in the advanced industrial democracies of the Organization for Economic Co-operation and Development (OECD) world, although we are aware of the fact that the literature on education policy in the developing countries and the role of democratization in promoting human capital investment is a growing area of research as well (see, for example, Baum \& Lake 2003; Brown \& Hunter 2004; Stasavage 2005).

To give an overview of the remainder of the article: in the following section, we introduce the reader to older as well as more recent work on the study of education from the perspective of comparative public policy. The subsequent section is concerned with literature that analyses the ubiquitous process of the internationalization of education and its interaction with domestic politics. Then, we discuss work on the comparative political economy of education and training, which is followed by a section on studies of the effects of education policies on socio-economic outcomes. Finally, we conclude by highlighting future avenues of research.

\section{THE STUDY OF EDUCATION IN COMPARATIVE PUBLIC POLICY}

Comparative public policy is generally interested in describing and explaining observed differences in policy output and outcomes across countries. In the words of

${ }^{1}$ See also Jakobi et al. (2009a) for an overview of new political science research on education. 
Heidenheimer, Heclo and Teich Adams, '[c]omparative public policy is the study of how, why, and to what effect different governments pursue particular courses of action or inaction' (Heidenheimer et al. 1990: 3). That is, rather than explaining the effects of education policies on social or economic outcomes, comparative public policy focuses on explaining which political, institutional or socio-economic factors determine the output of the policy-making system. We group the existing scholarship into two categories: first, an older strand of literature that is mostly concerned with explaining the differences in the development of education systems, rooted in comparative macro-sociology and historical institutionalism; secondly, a number of more recent studies that are concerned with explaining policy reforms in the contemporary period and with identifying the determinants of public and private investments in education.

\section{The Formation of Education and Training Regimes in Historical and Comparative Perspective}

Scholarly contributions by Arnold Heidenheimer (1973, 1981), Margaret Archer (1979, 1984, 1989), Andy Green (1990), Fritz Ringer (1979) and Abram De Swaan (1988) are good examples of an older strand of literature, which is located midway between historical macro-sociology and political science. The aim of these studies was to describe and explain differences in the institutional set-up of the educational system. Methodologically, these studies relied on qualitative and historical methods and small- $N$ comparisons.

Heidenheimer $(1973,1981)$, for instance, was mostly concerned with explaining how education had developed differently in the United States compared with how it had developed in European countries. He emphasized the importance of the relative timing of macro-social processes such as bureaucratization and democratization, although he also studied the influence of trade unions and professional interest groups. For Heidenheimer, the intense competition between local, state, private and religious educational institutions for students and resources fuelled the early expansion of higher education institutions in the United States, whereas in Europe, higher education institutions were important instruments to limit access to elite positions in powerful state bureaucracies (Heidenheimer 1981: 272).

The topic of decentralization also features prominently in the work of Archer (1979, 1984, 1989). Archer draws a fundamental distinction between the centralized and decentralized education systems that are associated with different types of policy making: in centralized systems, policy reforms have to be initiated through the centre of political authority, whereas in decentralized systems, institutional change can unfold below the radar of legislative politics because of local innovation (Archer 1989: 259-60). Most importantly, Archer criticizes contemporary educational sociology for not paying enough attention to both the 'cross-national' perspective and politics in general. The first task in developing a more comprehensive approach to the analysis of education systems is to study 'the social origins of educational systems; to account, in short, for why historically different nations generated varying structures of systems' (Archer 1989: 255). For Archer, politics and political decision making play an important role in this enterprise:

Being the political products of power struggles, [education systems] bear the marks of concession to allies and compromise with opponents. Thus to understand the nature of emergent education systems we need to know not only who won the struggle for control but also how; not merely who lost, but also how badly they lost out (Archer 1989: 258). 
Unfortunately, Archer's calls for a more historically oriented and politically sensitive sociology of education seem to have had only a minor impact on the further development of the discipline. ${ }^{2}$

The seminal work of Kathleen Thelen addressed an important research gap by exploring the development of vocational training systems in the United States, Britain, Japan and Germany (Thelen 2003, 2004; Thelen \& Kume 1999). Thelen's work is thus an important complement to the earlier work mentioned above, which focused more on the development of general (primary and secondary) and higher education and tended to neglect vocational education and training. With regard to the theoretical framework used, Thelen's work is rooted in historical institutionalism, industrial relations and comparative political economy (see below). In order to explain why vocational training systems developed in different directions, Thelen emphasizes the importance of the balance of power between different groups of actors. In particular, the preponderance of industrial unions over craft-based unionism and the politically supported continued viability of the crafts sector explain why firms remained committed to vocational training in countries such as Germany, whereas in others (Britain and the United States) apprenticeship training faced inexorable decline (Thelen 2004: 20-2).

An important common feature of the contributions made in this field of scholarship is the emphasis put on the role of time and timing (Archer 1979: 8; Heidenheimer 1981: 270; Thelen 2004: 31-3). Early events matter more than later events, because they have a strong impact on the selection of development paths (Pierson 2000). Power struggles mediated by institutions (such as the level of decentralization in education systems) at critical junctures in history determine the fate of education systems. What these studies neglect, however, is the role of political actors in the narrow sense, i.e. political parties. These play an important role in the field of scholarship to be introduced next.

\section{Quantitative Studies of Education Policies and Spending}

In addition to the historically oriented, small- $N$ studies introduced in the previous section, we find an emerging literature on the political, institutional and socio-economic determinants of policy output in education. Scholarship in this field differs from the previously introduced work on an important point: instead of identifying all the causes that led to the emergence of different education systems ('causes-of-effects' approach), it is more interested in assessing the impact of specific independent variables on education policy output ('effects-of-causes' approach, cf. Mahoney 2010). A significant part of this literature uses quantitative methods and large- $N$ research designs, sometimes combined with qualitative case studies. Mirroring a similar approach taken in comparative welfare state research, a number of studies in this field are concerned with identifying the determinants of education spending, i.e. public investments in human capital formation. These studies also borrow their theoretical framework from comparative welfare state research, i.e. questions are often asked such as 'Do parties matter?' (Schmidt 1996) or 'Do institutions matter?' (Weaver \& Rockmann 1993) in terms of their effect on policy output and outcomes. It is our intention, first, to present an overview of quantitative studies on

\footnotetext{
2 Notable exceptions are the more recent works of Heidenheimer (1997) and Windolf (1997). These studies explore the social and political origins and trace the historical development and expansion of higher education systems in Germany, the United States, Switzerland and Japan from the late nineteenth century to the present day (with Germany being the only case covered in both studies).
} 
education, especially on education spending. Subsequently, we will discuss qualitative work in this field of scholarship, which deals with explaining differences in policy making as well as in the governance of educational institutions.

A sizeable literature analyses the statistical determinants of investments in education. Early work in this tradition (Castles 1982; Verner 1979) revolved around the question of whether political variables were needed at all to explain education policy output or whether output was mostly driven by socio-economic forces. These early studies were hindered by the lack of internationally comparable data on the finance of education. ${ }^{3}$ With the exception of the work of Francis G. Castles $(1989,1998)$, the study of education policy output remained an unexplored subject for a long time. This is why, in recent years, some exploratory studies have rediscovered the field (Ansell 2008a, b; Boix 1997, 1998; Busemeyer 2007; Iversen \& Stephens 2008; Schmidt 2007). In an important contribution, Iversen and Stephens (2008) highlight the elective affinities between well-known welfare state typologies (Esping-Andersen 1990) and the 'three worlds of human capital formation' and call for a reintegration of education and training systems into comparative welfare state research (Iversen \& Stephens 2008: 602). ${ }^{4}$

Since Castles (1982), the role of government parties as a determinant of education spending has remained a prominent research question. Compared to the more classical objects of study in partisan theory (such as welfare state spending, as in Huber \& Stephens 2001), education is a peculiar case because the redistributive implications of increased investment in education, in particular higher education, are not as clear-cut as in the case of other social policies. What is more, skill-biased technological change has been identified as an important force mitigating the equalizing effects of investments in education, although, as Mosher points out, the balance of power between business and labour continues to influence the distribution of resources on the labour market (Mosher 2007).

On the one hand, parties of the left are expected to expand educational opportunities because unskilled or less skilled workers, being the core electorate of social democratic parties, have an interest in enhancing their human capital (Busemeyer 2007, 2009b; Castles 1982, 1989, 1998; Schmidt 2007). Carles Boix (1997, 1998) has made a very important contribution to the literature by highlighting the fact that social democrats' preference for investing in education should be seen as a consequence of changes in the economic context. Since the forces of economic globalization have made Keynesian demand-side management policies unfeasible, social democrats increase public investment in human and physical capital formation as their preferred supply-side strategy.

On the other hand, scholars have questioned whether investment in education is in fact a primary policy goal for leftist parties. A core finding of the sociological literature is that the upper classes have privileged access to education, particularly higher education

\footnotetext{
${ }^{3}$ Even today, scholars continue to worry about the reliability of international education statistics. One bone of contention, for example, is whether to include the expenditure of German firms on vocational training in the official education budget (see Heidenheimer 1996). Another example is the distinction between public expenditure on educational institutions (i.e. public funds that flow to education institutions) and total public education expenditure, which includes public spending not directed at educational institutions, but related to the acquisition of human capital (such as subsidies for costs of living via scholarship programmes or reduced health care contributions for students; see OECD 2008: 200). Nevertheless, the increasing involvement by international organizations such as the OECD, the World Bank and UNESCO in education policy has significantly improved the availability of crosssectional and time-series data on education outcomes and inputs.

${ }^{4}$ See, for a similar explorative study, Hega and Hokenmaier (2002).
} 
(Stevens et al. 2008). Hence, the redistributive potential of education is lower than that of more traditional transfer policies, so that parties on the left should not be expected to expand education at any cost (Ansell 2008b, 2010; Jensen 2011). Busemeyer (2009b), however, finds that the participation of social democrats in government is associated with increases in public spending on higher education - a result that he explains as attempts by leftist parties to reach out to new voting groups in the middle classes.

Other intensively studied topics in this field concern the division of labour between public and private sources of finance for education (Wolf 2009; Wolf \& Zohlnhöfer 2009), the impact of population ageing on education spending (Poterba 1997; Wolter \& Cattaneo 2009) and the relative impact of age and class on individual-level spending preferences (Busemeyer et al. 2009). Tepe and Vanhuysse (2009) provide evidence for the existence of political business cycle effects in the hiring policies for teachers in German Länder, i.e. governments hire more teachers when elections are imminent. Busemeyer (2008) shows that education spending, in contrast to other types of social spending, is positively associated with fiscal decentralization.

\section{Qualitative Studies on Education Policies and Governance of Educational Institutions}

In contrast to the increasing number of quantitative studies, there are surprisingly few studies that compare education policy output from a more qualitative perspective. Of course, scholarship in the neighbouring disciplines such as the comparative education sciences provides abundant empirical material on contemporary education systems, but these kinds of studies often focus more on describing the differences between education systems rather than explaining them. If they engage in the latter, theoretical frameworks tend to be borrowed from education sociology, organization theory or management studies rather than political science. Furthermore, comparative education science and sociology are more interested in the effects of education policies on social indicators and societal outcomes (see later) rather than the political and institutional factors that explain their enactment. In any case, the kind of medium- $N$ studies on processes of policy change prevalent in comparative welfare state research (e.g. Huber \& Stephens 2001; Pierson 2001) are lacking so far.

However, we find a few exceptions to this general rule. Following in the footsteps of Heidenheimer, scholars such as Ansell (2008a, 2010) and Lindert (2004) have emphasized the deep connection between education and democracy. Ansell (2008a, 2010) relies on quantitative and qualitative analyses of educational politics and policies, engaging in an impressive tour d'horizon spanning the world of both developing and developed countries and examining both historical and contemporary developments. In addition to partisan politics (see above), Ansell finds that democracy and democratization are positive driving forces of educational expansion, not just historically but also in contemporary developing countries. Lindert (2004: chap. 15) also emphasizes the importance of democratic voting rights as driving factors in the expansion of mass public schooling starting in the late nineteenth century and continuing over the course of the twentieth century. Lindert's work is also remarkable with respect to the way education is treated as an integral part of the welfare state. Another attempt to integrate the study of education with questions of social equality and cohesion is the edited volume by Green, Janmaat and Preston (2006).

In addition to studies on democracy and education, an important area of qualitative scholarship consists of studies on the governance of education institutions. This topic 
spans different disciplines and seems to be a useful focal point around which scholars from political science, sociology and the education sciences might come together. In contrast to standard approaches in comparative public policy, this line of research is less interested in explaining differences in policies than in assessing the impact of policies on the governance of and distribution of power within educational institutions (Enders 2004). To return to the influential book by Burton R. Clark (1983), scholars in this field are interested in comparing and describing cross-national differences in the way educational institutions are organized and govern themselves (for example, Becher \& Kogan 1992; Goedegebuure et al. 1994). The lasting contribution of Clark has been to provide a triangular set of diverging forces - academic oligarchy, state authority and market forces - that have proved helpful in explaining both the tensions within the governance of higher education as well as cross-national differences in higher education systems. Reflecting the lack of interest in the determinants of policies, Clark (1983: 2-4) actively encouraged the study of governance mechanisms in educational institutions independently of the surrounding political context, because he regarded higher education as a (semi-)autonomous sub-system of society. ${ }^{5}$ Policies (and their reform) feature as exogenous factors in some works, upsetting and transforming the governance of educational institutions (for example, Musselin 1997), but the study of how this transformation of the political context (within and beyond educational institutions) feeds back into the policy-making process has not as yet become an integral part of the research agenda (Enders 2004: 373).

More recently, however, there seems to be some movement on that front. In particular, in the wake of widespread privatization and the introduction of quasi-markets in the provision of education, scholars have started to look at the politics behind the introduction of these reforms, which are aimed at transforming the governance of educational institutions. A comprehensive volume edited by Braun and Merrien (1999) assesses the impact of new public management reforms on higher education governance in a number of Western democracies. Lundahl (2002) provides an extensive overview of the role of government parties in Swedish education reform during recent decades. Ball (1993) and the volumes edited by Ahier and Esland (1999) and Flude and Sieminski (1999) study the case of Britain, distinguishing themselves from the other contributions in that their perspective goes beyond higher education to encompass general and vocational education. Klitgaard (2007, 2008) compares the sometimes puzzling and paradoxical politics of school voucher reforms in the United States, Germany and Sweden. In a comprehensive comparison of the politics of institutional change in the higher education systems of Norway, Sweden and England, Kogan, Bauer, Beiklie and Henkel (2006) adopt a theoretical framework that borrows not only from the classical works in governance studies (Clark 1983; Becher \& Kogan 1992) but also from historical institutionalism and comparative public policy (cf. Bleiklie \& Kogan 2006: 10-15). Recently, the governance perspective has become a very popular approach in studying the internationalization of education policy (Jakobi et al. 2009a; see also later).

\section{Open Questions}

Open questions and potential issues for future research in the broad area of comparative public policy are the relationship between vocational training and higher education and

\footnotetext{
${ }^{5}$ See also these other influential volumes in the field: Becher \& Kogan 1992, Van Vught 1989.
} 
the association between the public and private provision of education as parts of the preferred policy packages of political parties. For example, it is not yet clear whether social democratic parties in government prefer investing in higher education or vocational training, whether this depends on the specific context of education systems or whether this relationship has changed over time. Similarly, conservative parties are often associated with limiting public investment in education and promoting market-enhancing governance reforms (Lundahl 2002), but Ansell (2008b, 2010) and Jensen (2011) find that conservative parties can, under specific conditions, also favour increased public investment in education because this is less distributive than social transfer spending.

Furthermore, very little is known about the individual-level determinants of policy preferences on education. Whereas, in comparative welfare state research, we find a large literature on individual-level preferences and positions with respect to the social state (e.g. Andress \& Heien 2001; Arts \& Gelissen 2001; Svallfors 2003), there is still a lack of similar research for the case of education. ${ }^{6}$

Finally, the governance of educational institutions will remain an important research topic for years to come, in particular in relation to the increasing internationalization of education systems (see subsequent section). A fruitful avenue for future research in this field would be to explore the role of policies and policy change in effecting real institutional change in the governance of educational institutions and the feedback effects of these changes on the distribution of political power in education policy making.

In the following section, we discuss studies on the rise of international organizations (IOs) as important players in education policy. This phenomenon has questioned one central assumption of comparative public policy, namely that national education systems and policies are independent from developments in the international political economy. However, political science has reacted quickly, and the issue of the internationalization and Europeanization of education policy has developed as a new research field.

\section{INTERNATIONALIZATION AND EUROPEANIZATION OF EDUCATION POLICY}

Since the late 1990s, the internationalization of education policy and the role of international organizations therein have increased enormously (Allmendinger et al. 2010; Powell \& Solga 2008; Jakobi et al. 2009b). The OECD has become an important player, comparing and assessing the performance of education systems, as in the now (in)famous Programme for International Student Assessment (PISA). Although the European Union (EU) is legally prohibited from harmonizing national education systems, its role in national education policy making has expanded considerably since the enactment of the Lisbon Strategy (2000) and the Bologna (1999) and Copenhagen (2002) Processes. While in Lisbon the European Union decided to make the EU 'the most competitive and most dynamic knowledge-based economy in the world by 2010', the Bologna and Copenhagen Processes induced reforms in national higher education and vocational training systems. In higher education, study structures have been reformed with the aim of improving the 'employability' of students (i.e. the introduction of the two-cycle study system consisting of bachelor and master's degrees). In vocational training, initiatives such as the European Qualifications Framework (EQF) and National Qualifications Frameworks (NQFs) are also aimed at increasing labour mobility by making educational qualifications more

${ }^{6}$ However, see Ansell (2010) and Busemeyer (2010). 
comparable. Whereas the Bologna Process has already strongly affected European universities with the introduction of new degree structures, the Copenhagen Process is still in progress and currently shaping discourses and the politics of initial vocational training. And finally, education is also included in the General Agreement on Trade in Services (GATS), which might in the long term contribute to a further privatization and liberalization of education.

Although nation states are still the primary actors in education policy, the internationalization and Europeanization of education policy can no longer be regarded as marginal, either from a substantive or a theoretical perspective: in terms of substance, European universities are completely changing their study structure, and in the process abolishing old European traditions which distinguished them from the liberal model. Benchmarking initiatives of the OECD and the EU are increasingly affecting public reform policies, and stakeholders in vocational training are on the way to formulating NQFs, which will link their vocational training systems to the EQF. In terms of theory, the reactions of national actors to the international initiatives show that domestic politics are often the driving force. Therefore, the internationalization and Europeanization of education policy needs to be analysed with theoretical approaches at the interface of comparative politics and international relations.

According to Jakobi et al. (2009b), the internationalization of education is now one of the main drivers of change in education systems. In their edited volume, these authors also stress that internationalization and Europeanization not only lead to the emergence of policy-making processes, structures and new actors in education at the international level, but also indicate a growing influence of IOs on national education systems. Hence, political science scholarship can be grouped as follows: (1) studies on the emergence of governance mechanisms and policy-making processes at the international level; (2) research into the effects of internationalization on national policies, polities and politics. Methodologically, the literature on internationalization and Europeanization mainly applies qualitative methods such as case studies, small- $N$ comparisons, content analysis or historical narratives.

\section{Governance Mechanisms and Policy-Making Processes at the International Level}

The internationalization of education policy is associated with the emergence of new governance structures and policy-making mechanisms at the international level. The most recent overview of the role of international organizations in education policy is provided by Leuze et al. (2008: 5), who analyse and classify the 'governance instruments' used by international organizations in education policy making, such as discursive dissemination, standard setting, financial incentives, co-ordination activities (for example, the EU's Open Method of Co-ordination (OMC)) and technical assistance.

We also find a number of in-depth case studies on the education policies of specific IOs such as the GATS or the EU, as well as on particular governance mechanisms such as the OMC. The studies of Scherrer $(2005,2007)$ and Verger (2009) discuss the role of GATS as a driving force of the privatization of education. Concerning EU education policy, the most comprehensive recent studies are those by Ertl (2006), Keeling (2006), Pépin (2007), Balzer and Rusconi (2007), and Walkenhorst (2008). On the basis of a content analysis of EU documents from 1970 to 2006, Walkenhorst reveals a shift in EU education policy from 'politico-economic' goals to 'economic-functional' goals, and hence to a pro-market orientation. He also argues that, at the EU level, an 'intensive transnational policy regime' 
has emerged which is driven forward by 'supranational entrepreneurship' (Walkenhorst 2008: 569). Besides the EU Commission, Walkenhorst names the European Court of Justice (ECJ) as well as the OMC as the key actors and instruments of EU education policy. Balzer and Rusconi (2007: 71) and Ertl (2003: 29) concur that the European Commission is the most important player at the EU level. The recent study of Borrás (2009) shows that, with the re-launching of the Lisbon Strategy in 2005, the role of the Commission changed. Whereas earlier it was confined to an 'administrative' function, it is now able to perform an ideological and political leadership function.

Bound by the legal prohibition to harmonize national education systems, the OMC plays an important role as a 'soft' governance instrument. However, as Gornitzka (2006) argues, its use still signals a watershed in European education policy. A reason for this might be the fact that, at different levels, states make strategic use of this instrument as a springboard for domestic reform politics (de Ruiter 2009).

With regard to the question of why international organizations increasingly become involved in education policy, the studies provide two main answers. On the one hand, the OECD, GATS and EU act as international and supranational policy entrepreneurs and use education policy to drive forward the liberalization and privatization of political economies as well as to expand their competencies (Scherrer 2005, 2007). On the other hand, internationalization can also be seen as a consequence of strategic decisions of national governments, public authorities and domestic socio-economic interest groups. In this perspective, the EU and its initiatives in education policy are exploited as a means to overcome reform blockades in domestic politics. The studies of Martens and Wolf (2006) and Nagel (2009) as well as the edited volume of Amaral, Neave, Musselin and Maasen (2009) illustrate this argument for the Bologna Process. Linking the international level with the national level also makes research into the internationalization of education policy of interest for those researchers studying the dynamic of two-level games. The study of the effects of international education policy on national systems is, therefore, the second major issue for research in this field.

\section{Effects of Internationalization on Domestic Policies, Polities and Politics}

Within the literature on the effects of internationalization on national education policy, polity and politics, the three major foci are as follows. First, there are studies which explain the effects on the basis of a multi-level perspective. These studies argue that IOs influence national systems, but their effect depends on domestic institutions, veto actors and politics (Martens \& Wolf 2006; Trampusch 2009). Secondly, another strand of literature understands the effects of internationalization as a process of policy learning and diffusion, emphasizing the role of ideas and processes of norm construction (Balzer \& Rusconi 2007; Jakobi \& Martens 2007; Jakobi 2009). An instructive overview of these two approaches is provided by Leuze et al. (2008). While these two strands of thinking are mostly adopted by political scientists, we can add a third perspective, which comes from education science, but which supplements the other two perspectives with an outcome-oriented analysis. Contributions to education science view education systems, occupations, qualifications, certifications, competencies etc. as socially constructed. Thus, they argue that, due to different national trajectories in constructing skills, convergence is unlikely although international organizations are increasingly engaged in education, as is, for example, the EU, with its initiative of establishing a European Qualification Framework (EQF) in the wake of the so-called Copenhagen Process 
(Brockmann et al. 2008; Clarke \& Winch 2006). Tellingly, Clarke and Winch (2006) ask: 'A European skills framework? - but what are skills?'

Research into the effects of IOs at the national level mainly benefits from detailed case studies (Trampusch 2008) or small- $N$ country comparisons (Dobbins \& Knill 2009; Trampusch 2009; Witte 2006). Witte (2006) analyses the implementation of the Bologna Process in France, Germany, the Netherlands and England. She shows that public authorities have used the Bologna Process to legitimize national reforms in higher education, and that not only domestic institutional veto points but also the domestic problem load are intervening variables in the process of Europeanization. The study of Dobbins and Knill (2009) assesses the degree of policy convergence in higher education policies in Central and Eastern Europe and shows that the Bologna Process has triggered national reforms in higher education in these countries as well. Trampusch (2009) analyses the effects of the Copenhagen Process on vocational training policy in Austria and Germany. Embedding the analysis of Europeanization in a more general analysis of institutional change, she concludes that, in Germany, Europeanization occurs as reform policies and politics; in Austria, however, Europeanization occurs more as institutional change by default, and hence without strategically enacted reform initiatives shaped by the EU and as domestic institutional change that occurs anyway.

The literature does not yet provide clear answers as to the impact of economic internationalization on the role of the state in the provision of education. Scherrer discusses the probable effects of including education as a tradable service in the GATS. According to Scherrer (2005), the direct effect of the GATS on national education systems is still low, although it helps to 'lock in liberalization measures', which are initiated outside the GATS negotiations by other IOs such as the OECD or the EU. In contrast to Scherrer, in his study of the effects of globalization on education, Ansell (2008a), relying on a quantitative research design, finds that under certain conditions, economic globalization is associated with the expansion of public education spending. Taken together, political and economic globalization have ambiguous effects on the states' role in education: on the one hand, economic globalization drives states to increase public spending; on the other hand, political globalization and Europeanization in this policy field is used in various countries as a means to a further privatization and liberalization of education (Bologna). To sum up, what are the main achievements of the research into internationalization and Europeanization in education policy, and where do we still find gaps?

A striking feature of this strand of literature is that it shows how political science has responded quickly to the new development of internationalization in education. Education policy is meanwhile an established research object in international political economy (IPE) and in the literature on Europeanization. Furthermore, the studies are empirically grounded, inductive and actor-oriented, exploring the new developments of internationalization and Europeanization by means of case-oriented qualitative methods in order to develop new hypotheses and theories. This kind of research design is a necessary precondition for further studies in this field, which may apply quantitative methods and deductive reasoning.

Nevertheless, three challenges should be mentioned. First, it is surprising that research into Europeanization and internationalization is less multi-disciplinary than that into the effects of education systems or the studies we discussed in the domain of comparative public policy and comparative political economy. The existing studies mainly search for political factors instead of linking their explanations of change to studies in sociology or education science, for example, which could provide our discipline with well-grounded hypotheses on the effects of cultural, socio-economic and institutional factors. 
Secondly, the studies mainly focus on the role of strategic reasoning, analysing internationalization and Europeanization as a matter of reform politics or reform ideas or policy learning. However, one may argue that political and socio-economic actors merely react in a trial-and-error fashion. Confronted with multiple international influences and opportunities, and raised in highly fragmented national education systems, political reformers may simply not know what will happen when they react to the OECD, the EU or GATS.

Thirdly, the effects of the internationalization and Europeanization of education policy on national democracies and identities as well as on democratic legitimacy are left by the wayside. This deficiency is astonishing in so far as education policy and education systems are not only linked to national trajectories of identity and sovereignty, but are also the result of historically evolved economic, social and democratic structures. It seems that education policy is no longer an autonomous domain of the nation states, which has far-reaching implications for the development of national democracies.

In sum, the research into internationalization and Europeanization may benefit not only from including a more comprehensive perspective on the growing influence of international organizations on education systems, but also from allowing more diversity into their theories. Moving beyond the assumption of strategic and rational actors, on the one hand, and connecting research into reform policies and politics in the context of internationalization and Europeanization with the analysis and theories of institutional change (Streeck \& Thelen 2005), on the other, are, in our view, the two main challenges with which this strand of literature is confronted. In this more actor-oriented perspective, questions of timing and sequencing are of interest, as it is still unclear why we observe this growing influence of international organizations increasingly since the 1990s and not earlier. ${ }^{7}$

\section{THE COMPARATIVE POLITICAL ECONOMY OF EDUCATION AND TRAINING}

Works in the tradition of comparative political economy are located at the interdisciplinary intersection between industrial relations, management studies, sociology and political science. The involvement of political science scholars in this field of work remained subdued until the 'varieties of capitalism' (VoC) debate (Hall \& Soskice 2001) brought the question of skill formation from the periphery to the centre of comparative welfare state research and political economy. A full review of the $\mathrm{VoC}$ debate goes beyond the purpose of this article, ${ }^{8}$ which is why we focus on those contributions that are concerned more specifically with education and training. However, before we discuss the VoC contributions and subsequent debates in greater detail, we would briefly like to document important forerunners and earlier contributions to the comparative study of the political economy of education and training.

\section{Industrial Relations, Education and Training}

A common element of the early and the later contributions is an analytical perspective rooted in neo-institutionalism. These works posited that the training decisions of firms

7 We thank Anja P. Jakobi for this insight.

${ }^{8}$ See Allen 2004, Howell 2003, Jackson \& Deeg 2006 for more comprehensive reviews of the VoC debate. 
could not be regarded as being independent of the institutional context that firms and other market participants were embedded in. In an influential contribution in the early stages of this literature, Finegold and Soskice (1988), for example, explained the failure of repeated attempts by the British government to establish a German-style dual apprenticeship training system by pointing out the differences in the socio-economic institutional framework between these countries. Along similar lines, Streeck (1989) argued that the kinds of institutions that encourage or even force firms to invest in the training of their workforce cannot be created by means of rational decisions taken by the firms themselves, but rest on political and social foundations and are imposed on firms in the form of 'beneficial constraints' (Streeck 1992, 2004). Intermediary associations such as employers' associations, chambers of commerce and trade unions were regarded as an important and integral part of the implementation process of these constraints (Streeck \& Schmitter 1985). The constraints proved to be 'beneficial' because they forced firms in co-ordinated market economies such as Germany to specialize in high-quality production strategies ('diversified quality production', cf. Streeck 1992), which went along with high wages for workers without academic credentials and thus contributed to an overall low level of social inequality. ${ }^{9}$ Streeck's concept of 'beneficial constraints' opens up space for political explanations, because ex ante it is an open question who (i.e. which actor) would be willing or able to impose the kinds of constraints on business that might be beneficial in enhancing human capital formation.

In the 1990s, much of the debate centred on identifying and explaining 'high skills models' and 'low skills traps'. The German case featured prominently in these debates as a positive role model (Franz \& Soskice 1995; Soskice 1994, 1999), but Japan and - with reservation, because of the lack of employer involvement in training - the Scandinavian countries were perceived as successful models as well (Ashton \& Green 1996; Brown 2001; Crouch et al. 1999; Culpepper \& Finegold 1999; Green 2001). More recently, scholars from the comparative education sciences have become increasingly interested in the institutional and 'international' context of vocational education and training, which has led to the publication of a number of edited volumes on the international comparison of Vocational Education and Training (VET) systems (Clarke \& Winch 2007; Bosch \& Charest 2010).

These works provide an abundance of empirical material on the contemporary - as well as partly on the historical - development of training systems in the major economies. Scholarship in this field has been very aware of the institutional complementarities between skill formation, industrial relations and labour market institutions, and scholarly interest in studying the connections between education and welfare state policies is increasing, as will be shown in the next section. From a political science perspective, issues such as the role of electoral politics, political institutions and government partisanship as important factors shaping educational institutions and education policy output remain under-researched. Policy change is often treated as an exogenous, independent variable (as when studying the impact of policies on institutional change). Therefore, the

9 The so-called Rehn-Meidner model, a popular point of reference in Swedish economic policy making in the 1970s and 1980s, is based on a similar logic. The centralization of wage bargaining forces unproductive firms either to invest in training their workforce or to go bankrupt. However, in the 'Scandinavian' version of beneficial constraints, the state plays a more prominent role, promoting the re-location of human capital into more productive firms via active labour market policies. We thank one of the reviewers for pointing this out to us. 
application of political science theories on the social and economic determinants of policy change to the empirically rich material provided by this strand of literature seems a very fruitful way to stimulate interdisciplinary discussion.

\section{Skill Formation in Varieties of Capitalism}

In the 'varieties of capitalism' (VoC) literature, the issue of skill formation or, more specifically, the skill demands of employers in interaction with political and economic institutions is the crucial factor explaining the divergent development paths of welfare state and production regimes (Hall \& Soskice 2001; Iversen 2005; but see also Crouch \& Streeck 1997; Hollingsworth \& Boyer 1997; Estévez-Abe et al. 2001; Iversen \& Soskice 2001; Kitschelt et al. 1999; Mares 2003; Soskice 1999). In co-ordinated market economies (CMEs), employers rely on non-market forms of co-ordination via strong employers' associations and corporatist institutions that facilitate cross-class compromises. In this institutionally dense environment, employers invest in the formation of industry, occupation and firm-specific skills and support generous welfare state policies because these policies help to convince workers to co-invest in these specific skills (Estévez-Abe et al. 2001; Iversen \& Soskice 2001; Mares 2003). In contrast, employers in liberal market economies (LMEs) (have to) rely on market mechanisms to co-ordinate economic action. This more competitive environment prevents and punishes skill investments by firms, so that skill formation largely takes place in formal education on the one hand and on-thejob training on the other. Instead of fostering cross-class compromise, the issue of skill formation has been contested across the class divide (Thelen 2004: 21) as craft unions aim at controlling access to skilled labour and employers, in turn, try to reduce their reliance on skilled workers by increasing the capital intensiveness of production. The availability of different kinds of skills - specific skills in CMEs, general skills in LMEs - is associated with distinct comparative advantages of firms in international product markets. According to Hall and Soskice (2001), firms in CMEs specialize (and are successful) in the production of diversified quality products (Streeck 1992), i.e. specialized niche products in high-end markets, often in manufacturing, chemicals and the car industry that rely on incremental innovation. In contrast, LME firms have a competitive advantage in cutting-edge technology in new economic sectors such as high-end services, information technology (IT) and biotechnology, which require radical innovation and swift adaptation to changing market conditions. The success of the Scandinavian countries in IT, however, does not really fit with the neat classification of countries into LMEs and CMEs, as these countries are usually regarded as CMEs and their training and education systems are geared at combining the provision of general and specific skills at a high level. ${ }^{10}$

The strength of the VoC school is that it yields concrete hypotheses about institutional complementarities between skill formation and the welfare state, which are open to empirical investigation. Strong vocational training institutions and a generous welfare state encourage investments in occupational skills, which enhance the competitiveness of CMEs in diversified quality production. An emphasis on higher education, in preference to vocational training, and deregulated labour markets that produce high wage premiums for college education in LMEs, bolsters competitiveness in radical product innovation. Since the publication of Hall and Soskice (2001), these claims have been vetted from different perspectives.

${ }^{10}$ See Iversen and Stephens 2008. We thank an anonymous reviewer for raising this important point. 
One strand of the literature is concerned with the implications of the $\mathrm{VoC}$ arguments on the micro level. Iversen and Soskice (2001) show that skill specificity is a positive determinant of social policy preferences, i.e. workers with specific skills are more in favour of increasing social spending. Cusack, Iversen and Rehm (2006) largely corroborate these findings and provide more macro-level evidence. According to their study, countries with 'specific skill systems' (i.e. strong vocational training institutions) respond to economic shocks by expanding public spending to a greater extent than countries with weak vocational training systems (Cusack et al. 2006: 383-4).

However, we also find studies that question the validity of the positive association between skill specificity and social policies. Kitschelt, for example, posits that the status of blue-collar employment is a more important determinant of redistributive preferences than skill specificity as such (Kitschelt 2006: 414). Furthermore, Kitschelt argues that those types of social policies that are closer to the employment sphere, such as unemployment insurance, should matter more than other, less directly related types, i.e. pension and health insurance (Kitschelt 2006: 414). In addition, we find a number of empirical studies that have analysed the 'asset specificity' thesis. Lee (2007), using data for the United States, finds partial support for the VoC thesis and introduces an interesting twist into the argument. According to his interpretation of the empirical evidence, workers with specific skills support unemployment protection because they find themselves trapped in a shrinking labour market due to de-industrialization and lack the necessary general skills required to update their skill portfolio (Lee (2007): 708). In contrast to Lee, Emmenegger (2009) again relies on internationally comparative data, so that his results are comparable to Iversen and Soskice (2001). Furthermore, borrowing from Goldthorpe (2000), Emmenegger argues that skill specificity might have a different impact on perceived labour market risks than that assumed by Iversen and Soskice (2001). On the one hand, skill specificity increases labour market risks, because workers will not be able to switch easily to a different job using the same skill set. On the other hand, high levels of skill specificity reduce the probability that the employer will dismiss the worker, because such workers are hard to replace. As a consequence, workers with specific skills should worry less about labour market risks and hence demand less unemployment protection. Emmenegger finds stronger support for the latter 'replaceability thesis' than for the 'asset specificity thesis'. Against these empirical studies, Busemeyer (2009a) revisits the concept of 'asset specificity' from a theoretical perspective (see also Huo 2009). In an attempt to clear the mist surrounding the conceptual foundations of the definition and operationalization of 'specific skills', he argues that the variety of skill regimes needs to be classified along two dimensions instead of one: the involvement of firms in skill formation, and the vocational specificity of the education system as such. ${ }^{11}$ Busemeyer (2009a) identifies three distinct skill regimes in co-ordinated market economies that are, in part, reminiscent of the 'three worlds of human capital formation' (Iversen \& Stephens 2008; see also Busemeyer \& Nikolai 2010).

In defence of Iversen and Soskice, it can be argued that their model includes both the 'specific' risk of skill investments as well as more general labour market risks (see also Cusack et al. 2006), which might be related more to the general level of skills rather than different kinds thereof. Also, as pointed out by Kitschelt, the relationship between skill specificity on the one hand and income and class on the other is more than superficial.

${ }^{11}$ See Blossfeld 1992 for a similar reasoning. 
Whereas Kitschelt, in line with Goldthorpe, provides a more 'sociological' perspective on occupations and classes, Iversen and Soskice clearly adopt a political economy perspective of class. Income and skills are at the heart of this debate, and Iversen and Soskice convincingly show that in addition to the overall level of skills, investments in different kinds of skills (however they might be called) have a strong impact on labour market stratification.

A long-held criticism of the VoC school is that its characterization of LMEs and CMEs is too 'Platonistic', disregarding institutional change, while overemphasizing the stability of production regimes, and neglecting the study of the historical and political foundations of skill regimes (Becker 2007; Korpi 2006; Stephens 2006; Streeck 2009). Explaining institutional change has by now become an important issue on the research agenda (Streeck 2009; Thelen 2007; Thelen \& Busemeyer 2008), although comparative studies of institutional change in vocational training from a $\mathrm{VoC}$ perspective remain rare (Busemeyer \& Trampusch 2011; Trampusch 2010a, b). The edited volume of Busemeyer and Trampusch (2011) provides in-depth studies of the evolution and contemporary change of collective skill formation systems, not only in a comparative but also in a historical perspective. Trampusch (2010b) shows that patterns of transformative and self-preserving change in collective training regimes are influenced by the employers' constellation and their interaction with elites of the public education administration. Bosch and Charest (2008) look at how the ability to adapt to a changing socio-economic environment varies between LMEs and CMEs and argue that differences between the two remain important (see also Anderson \& Hassel 2007; Bosch \& Charest 2010; Culpepper \& Thelen 2008). Toner (2008) studies the 'survival and decline' of apprenticeship training in the Australian and British construction industries, respectively. Toner emphasizes the institutional embeddedness of training systems and argues that apprenticeship training has a higher chance of survival in Australia because its institutional setting contains a number of CME elements, although this country is widely considered to be an LME.

Besides the question of institutional change, exploring the origins of contemporary varieties of capitalism has likewise become an important new field of research. The initial VoC contributions (Hall \& Soskice 2001; Estévez-Abe et al. 2001) specifically refrained from providing explanations of the origins of different varieties of capitalism and focused instead on understanding the effects of given institutional arrangements. Over time, proponents of the $\mathrm{VoC}$ school became more engaged in exploring the historical dimension, and the skill demands of employers remained the crucial independent variable in explaining the emergence of different production and welfare state regimes (Mares 2003; Swenson 2002). For Cusack, Iversen and Soskice (2007), the introduction of PR systems in countries that were later characterized as CMEs hinged on the support of employers, who viewed PR as an effective means to create the cross-class co-operation required to promote investment in 'co-specific' assets (see also Iversen \& Soskice 2009).

Several authors have questioned the thesis that the skill demands of employers are the driving force behind electoral systems and welfare states. Most prominently, Korpi (2006) posits that the strength of organized labour remains the crucial variable in explaining the origins of welfare states. In a response to Korpi, Iversen and Soskice (2009) emphasize that their argument about the role of employers does not imply that unions are irrelevant. Rather, the joint investment of labour and business in 'co-specific assets' facilitates the emergence of cross-class coalitions, which in turn propagate the shift from majoritarian to proportional (PR) electoral institutions. Further exploring the relationship between political and economic institutions, Martin and Swank (2008) argue that political factors 
such as the electoral system explain the divergent strengths of employers' associations, and this in turn determines whether co-ordinated or uncoordinated economies will form. In a similar vein, Trampusch (2010a), relying on case studies of Denmark, the Netherlands and Switzerland from 1870 until 1940, argues that the establishment of unemployment insurance was primarily motivated by the 'logic of organization building of capital and labour' rather than the skill demands of employers.

Besides the role of employers, another important issue is the question of whether modes of co-ordination are self-reinforcing equilibria or unstable social arrangements in need of particular institutional and political support. Culpepper (2003, 2007), for instance, emphasizes the fragility of collective vocational training arrangements (see also Culpepper \& Thelen 2008; Soskice 1999). By comparing East Germany and France to West Germany, Culpepper (2003) finds that the sustained viability of collective forms of skill formation needs the continued political support of political and economic actors and cannot be created from scratch. This finding mirrors earlier arguments by Streeck (1992), who stressed the importance of associational networks in nurturing a supportive 'institutional ecology' for training arrangements. Martin (2000) found that, even in LMEs such as the United States, the embeddedness of firms in business networks and associations has a significant positive impact on their support for social policies that promote the formation of human capital.

Summing up, the variety of capitalism debate has rendered an enormous service to those political scientists who are interested in exploring the institutional complementarities between education, the labour market and other welfare state policies. The original purpose of Hall and Soskice (2001: 2) to open up a new research agenda on these issues is certainly being addressed. However, although this has not been discussed here at length, our impression is that despite its prominent place in the theoretical discussion, skill formation and the politics of education and training reform in particular have been addressed to a lesser extent in the ensuing debates than other issues such as labour market policies, financial regulation, corporate governance and industrial relations (Jackson \& Deeg 2006). Furthermore, following along the lines of Iversen and Soskice (2001), a significant proportion of the research into the connection between skills and social policies has concentrated on the micro level, neglecting theorizing and empirical research at the macro level. Still, the issue of the political and historical foundations of today's education and training regimes needs to be explored further, in particular for those countries beyond the group of 'usual suspects', for example the Scandinavian and East Asian countries. Finally, the VoC school assumes positive complementarities between education and other social policies. More attention should be paid to those instances when education and social policy are in conflict with each other, such as in the competition for scarce public funds.

\section{EFFECTS OF EDUCATION POLICY AND SYSTEMS}

In contrast to the previously discussed fields of research in education policy, the study of the effects of education policy and systems is well established in the social sciences. Education and its quality are of primary importance not only for individual earnings (Nickell 2004) and economic growth (Barro 2001; Hanushek \& Kimko 2000), but also for social integration, equality of opportunity (Allmendinger et al. 2009) and, in particular, for transitions into the labour market (Allmendinger 1989). As outcomes of policies decisively influence the formation of policy preferences and political coalitions, 
understanding these effects and analysing how educational institutions interact with individual and socio-economic factors are of primary interest for political scientists.

Recently, the debate on the effects of education policy has been strongly invigorated by the spread of international student achievement tests and benchmarking reports of the EU and the OECD, measuring the educational performance of students. ${ }^{12}$ In this respect, the internationalization of education policy also promotes research on the effects of education policy (Allmendinger et al. 2010: 315-16) - in particular, studies with a crosscountry comparative perspective (Wössmann 2007). However, although more than three decades of research has been dedicated to studying the socio-economic effects of education systems, Schuetz, Ursprung and Woessmann (2005: 1) rightly point out that ' $[t]$ he direction of effects is ... by no means straightforward from a theory point of view, and empirical evidence is limited'. Nevertheless, it is common knowledge among economists and sociologists that educational performance and students' opportunities are not only determined by individual features and choices or the parental background, but also by institutions, and hence features of school systems.

Research into the effects of education policy analyses the performance of education systems in terms of social equality and labour market outcomes. Besides this focus, we also find studies examining the effects of education on social and political participation (Helliwell \& Putnam 1999), on participation in criminal activities (Lochner \& Moretti 2004) and on health (Feinstein 2002). Sociologists and economists dominate this line of research, and only recently, in the wake of the PISA study, have political science scholars become more interested (Schlicht et al. 2010). In particular, the PISA study has increased the availability of international comparable datasets on educational achievements and has brought a shift in the measurement of educational performance (Allmendinger et al. 2010: 314-15): Although educational performance was measured earlier by the length of a person's school attendance or the certificates the pupils had earned, the PISA studies focus on cognitive competencies. ${ }^{13}$ This shift in perspective also brings to attention some interesting analytical problems on the relationship between educational certificates and actual skills, because classifying the performance of education systems on the basis of certificates or competencies produces different country rankings (Allmendinger et al. 2010: 314-15). The increased interest in studies of educational performance in the wake of the PISA studies has also weakened the dominance of US research in this field of scholarship (Dronkers \& Robert 2008).

In the literature on the effects of education policy and systems, two key questions are addressed. First, how can we measure the effects of education policy? Secondly, which factors determine educational performance? With regard to the dependent variables of interest, research focuses on the socio-economic performance of education systems (economic performance, social equality), student achievements (such as the duration of a pupil's school attendance, certificates and competencies), social and educational equality (for example, achievements among social groups) and stratification (like occupational opportunities), and the transition into the labour market (such as occupational status,

12 See Wössmann (2007: 478-9) and Ammermüller 2005. Before PISA, quantitative data on the educational performance of students was provided by the Third International Mathematics and Science Study (TIMSS), released by the IEA (International Association for the Evaluation of Educational Achievement) in 1997 and 2001. In 2003, the IEA released data conducted within the Progress in International Reading Literacy Study (PIRLS) (Wössmann 2007: 479).

${ }^{13}$ PISA 2000: reading skills; PISA 2003: competence in mathematics; and PISA 2006: competences in natural sciences. 
career trajectories) (Allmendinger 1989). Besides finding internationally comparable proxies and indicators, the general question of how to measure educational achievements and the human capital stock of labour forces is still a challenge (Hanushek \& Kimko 2000): for example, Hanushek and Woessmann (2008) have recently shown that the cognitive skills of the population rather than just school enrolment and attainment affect individual earnings and economic growth.

Causal analysis of the social and economic effects of education policy research adopts two main theoretical perspectives (Allmendinger et al. 2009; Kupfer 2009): the conflict-oriented perspective (Bowles \& Gintis 2000; Collins 1979) and the functionalist perspective. Conflictoriented approaches argue that educational systems reproduce existing class relationships in society. This approach also draws on Pierre Bourdieu's (1984) social field approach. In this perspective, educational attainment is not determined by talent or motivation, but following Marxist class theory - by the individual's position in the hierarchy of classes. The functionalist perspective maintains that there are equal opportunities for students to attain highly skilled qualifications and that the main determinants for individual educational success are individual motivation and talent (Allmendinger et al. 2009: 50).

Besides individual talent and class position, a relatively new line of research points to the importance of institutional factors, such as the specific design of the school system. The seminal study by Jutta Allmendinger (1989) suggests that individual choices about schooling and, with it, individual labour market outcomes 'are significantly shaped and constrained by the opportunities the environments offers' (Allmendinger 1989: 231). She argues that both 'individual and environmental factors interactively affect mobility processes' (Allmendinger 1989: 232). The volume edited by Burtless (1996), Does Money Matter?, which analysed whether added school resources improve student achievements, was equally seminal in this strand of literature. One main finding of the studies in the edited volume was that the effect of spending on schools or student achievements is empirically less straightforward than economists and sociologists assume (Burtless 1996: 21-3). Currently, research focuses on the following features which affect the equality of educational opportunity (Ammermüller 2005: 2; Schlicht et al. 2010): use of streaming and institutional tracking of pupils, public vs. private schools, and school choice (Ball 1993; Dronkers \& Robert 2008), the amount of instruction time, pre-school enrolment and duration, school autonomy and decentralization (Chubb \& Moe 1990), the availability of pre-school education, all-day school tradition, class size and education expenditure.

Methodologically, quantitative studies dominate, although the theoretical relationships between potential independent and dependent variables are less clear than one would assume. The theoretical mis-specification is reflected in the fact that various empirical studies come to quite different conclusions concerning the effects of the institutional features of education systems on educational opportunities.

The results of the quantitative studies strongly depend on the data and methods used and the model specifications of regression and multi-level analysis. Quite often, different studies come up with different results and conflicting findings concerning the effects of particular institutional features on educational opportunities (cf., for example, Ammermüller 2005; Gamoran \& Mare 1989; Hanushek \& Wössmann 2005; Schuetz et al. 2005; Schlicht et al. 2010). For example, Schlicht et al. (2010) find that in Western (in contrast to former communist) countries of the European Union, all-day schooling rather than the pre-school tradition, private school tradition or tracking/streaming (i.e. the existence of different tracks for academic and vocational education in secondary education) affects social inequality in education. Other studies, however, have found that 
early tracking (Ammermüller 2005; Gamoran \& Mare 1989) and private school traditions (Ammermüller 2005; Ball 1993) determine the educational opportunities of students. Likewise, the effect of decentralization and school autonomy on students' achievements is highly contested (Chubb \& Moe 1990; Clune \& Witte 1990; for an overview, see Nikolai 2009; West et al. 2010; Wössmann 2007). Ammermüller (2005: 28) also rightly acknowledges that 'the effects of schooling institutions depend always on the implementation of policies within individual countries', which are hard to measure.

What can be learned from the studies of the effects of education policy and where do major gaps remain? To sum up, the study of the effects of education policy poses four challenges to political science. First, there is a theory problem. Quantitative studies have made huge progress in cross-country comparisons, and they convincingly show that individual factors as well as institutional features of education systems strongly influence educational outcomes. However, despite the high number of well-conducted empirical studies, applying sophisticated statistical methods, systematic considerations of how individual and institutional factors interact with each other are lacking. Although this micro-macro problem is one of the core questions of social science, reasoning on probable causal mechanisms that link the micro and macro levels is still missing from virtually all but the work of Allmendinger (1989). Hence, there is an enormous disproportion between investments in data analysis and in theories, although in the end it is always theory which should justify the formulating of complex regression models. It seems that research is more guided by the availability of data than by theoretical considerations.

Secondly, research into the effects of education systems is not only isolated from the other strands of literature on education policy, but also there is a lack of communication within existing studies of the effects of education policy. It is uncontested that education policies affect labour market performance, social equality or sociopolitical outcomes such as health, criminality or social integration. However, one cannot discern any research effort to bring these results together in order to produce an overall account of education policy effects. Studies that review existing analyses, summarize the main results and identify where gaps remain are rare (exceptions are Hanushek 1986; Wössmann 2007). This means that, although the effects of education policies have been comprehensively studied, political actors are still in need of clear, practicable and implementable recommendations arising from the research.

Thirdly, the historical and political foundations of education systems as well as the role of actors, politics and the implementation of education policies are still largely a 'black box'. Moira Nelson's work shows impressively how comparative historical analysis can be combined with the study of the effects of education policies on labour markets (Nelson 2008).

Fourthly, we can also discern that, in analysing the effects of education policy, research has neglected probable links between education policy and other policy fields such as social policy. According to Allmendinger and Leibfried (2003), education and social policy are closely interconnected in producing educational poverty, educational resources and competencies. Studying such effects in more detail may also allow us to link research on the effects of education policy with the welfare regime and the VoC approaches, which are so important in comparative political economy.

\section{CONCLUSIONS}

The primary purpose of this review article is to provide an overview of the state of affairs in the study of education from the perspective of comparative political science. We have seen that, after a long period of neglect, political science research in this field is expanding rapidly. 
In the conclusion of their edited volume, Jakobi, Martens and Wolf (Jakobi et al. 2009a: 224-7) name several research topics that political science might address in further research on education: the internationalization of education, path-dependence and change of path, new actors and actors' networks, administrative changes due to reforms, normative questions, economization and education, and the relation of education to other policy fields. In their view, unlike other disciplines such as education science, sociology and economics, "political science is obviously the discipline that is mainly and primarily focused on "the political" in education policy, comprehensively understood as the analysis of policy, politics, and polity' (Jakobi et al. 2009a: 222). Although we agree with this statement, on the basis of our review it seems reasonable to argue that political science should not include only 'education' as a research object akin to other policy fields. If we intend to understand the complexity of education policy, it is not sufficient to focus on the role played by political factors. In fact, our conclusion is that one of the main tasks political science has to perform is to learn from research on education in sociology, economics and education science. Hence, we strongly favour a multi-disciplinary research perspective instead of further isolation of the different disciplines. We see several bridges which may link the different perspectives. In so doing, we focus on the four strands of literature that we have just discussed.

First, our review of the studies in comparative public policy has shown that we already know plenty about 'how, why, and to what extent' (Heidenheimer et al. 1990: 3) governments, political parties and socio-economic actors pursue different strategies in education policy. However, in the comparative analysis of education policy, there are still some black boxes, such as the relationship between higher education and vocational training, the relationship between public and private provision, and the influence of political parties on both these issues. One way to open these black boxes could be to analyse in more detail the governance of education systems in a comparative perspective, i.e. the way public policies impact on the distribution of authority and power within educational institutions and how, in turn, this distribution of power feeds back into educational policy making. The great advantage of this focus is that governance spans different disciplines, encouraging interdisciplinary exchange.

Secondly, our review of the literature of the internationalization of education policy has revealed that one challenge here is to move beyond the analysis of political factors by incorporating not only cultural and socio-economic factors but also more variability in the way we conceive the reaction of actors to international 'pressures'. Here, we argue that linking the analysis of the relationship between internationalization and domestic policies, politics and polities with theories of institutional change may be helpful in understanding the timing, the reasons and the consequences of the growing role of international organizations. Hence, with reference to this strand of literature, theories and frameworks on institutional change in education systems may be a way to bridge the perspectives of different disciplines.

Thirdly, our discussion on the comparative political economy of education and training has shown that the political and historical foundations of education systems together with positive complementarities of education and social policy need to be explored further. ${ }^{14}$ With respect to this strand of literature, we conclude that answering these two open questions would enable studies in comparative political economy to be linked more closely

14 Nice examples of recent work in this line of research are Nelson 2008 and Trampusch 2010a. 
to studies in comparative public policy, because the second offers some very interesting insights into the historical conditions and the politics of the formation of education systems.

Fourthly, our review of the literature on the effects of education policy has shown that studies in this domain would benefit from theoretical work on the micro-macro problem in understanding outcomes of education policy as well as from incorporating insights into the historical and political foundations of education systems. Bringing together scholarship on the effects of education policy with the literature in comparative public policy and comparative political economy would thus allow a more comprehensive understanding of the policy-making cycle to be developed as it unfolds over time.

In sum, we firmly believe in the value of interdisciplinary exchange, combining the comparative advantages of social science sub-disciplines. With regard to the distinctive strength of comparative political science, Fritz W. Scharpf (2000: 762-3) pointed out that comparative public policy analysis in particular is more concerned with analysing processes of decision making and the interaction between political actors than the nature of societal problems and their solutions by means of policies. Scharpf identified those as the domain of economists and sociologists. In our view, this - admittedly overdrawn classical perspective of comparative political science should be broadened to incorporate insights into the study of education from related disciplines without giving up the particular focus on political questions.

In particular, taking into account the effects of policies on socio-economic outcomes and the distribution of power within educational institutions as well as in the political arena would provide a more thorough understanding of how 'policies shape politics' (Pierson 2004), i.e. how the policy choices of previous periods shape the political playing field of the subsequent round of political decision making. In addition, studying the effects of policies would also help to address the more general question about the relationship between policy and institutional change. Clearly, not every policy change triggers change in educational institutions and, conversely, the character of educational institutions can change quite significantly even without any large-scale changes in policies. So far, this relationship remains unexplored, both from a theoretical and from an empirical perspective. Eventually, the effects of educational policy choices on social equality would help to reintegrate the study of education into comparative welfare state research. The varieties of capitalism debate provides an appropriate 'access route' to studying these complementarities between education, welfare states and political institutions.

\section{LIST OF REFERENCES}

Ahier, John, and Geoff Esland, eds, Education, Training and the Future of Work II: Social, Political and Economic Contexts of Policy Development (London: Routledge, 1999).

Allen, Matthew, 'The Varieties of Capitalism Paradigm: Not Enough Variety?' Socio-Economic Review, 2 (2004), 87-108.

Allmendinger, Jutta, 'Educational Systems and Labor Market Outcomes', European Sociological Review, 5 (1989), 231-50.

Allmendinger, Jutta, Christian Ebner, and Rita Nikolai, 'Soziologische Bildungsforschung', in Rudolf Tippelt and Bernhard Schmidt, eds, Handbuch für Bildungsforschung (Wiesbaden: VS Verlag für Sozialwissenschaften, 2009), pp. 47-70.

Allmendinger, Jutta, Christian Ebner, and Rita Nikolai, 'Education in Europe and the Lisbon Benchmarks', in Jens Alber and Neil Gilbert, eds, United in Diversity? Comparing Social Models in Europe and America (Oxford: Oxford University Press, 2010), pp. 308-27. 
Allmendinger, Jutta, and Stefan Leibfried, 'Education and the Welfare State: The Four Worlds of Competence Production', Journal of European Social Policy, 13 (2003), 63-81.

Amaral, Alberto, Guy Neave, Christine Musselin, and Peter Maasen, eds, European Integration and the Governance of Higher Education and Research (Dordrecht: Springer, 2009).

Ammermüller, Andreas, 'Educational Opportunities and the Rolfe of Institutions', ZEW Discussion Paper, no.05-44 (2005).

Anderson, Karen, and Anke Hassel, 'Pathways of Change in CMEs: Training Regimes in Germany and the Netherlands' (paper prepared for the American Political Science Association Meeting, Chicago, 2007).

Andress, Hans-Jürgen, and Thorsten Heien, 'Four Worlds of Welfare State Attitudes? A Comparison of Germany, Norway, and the United States', European Sociological Review, 17 (2001), 337-56.

Ansell, Ben W., 'Traders, Teachers, and Tyrants: Democracy, Globalization, and Public Investment in Education', International Organization, 62 (2008a), 289-322.

Ansell, Ben W., 'University Challenges: Explaining Institutional Change in Higher Education', World Politics, 60 (2008b), 189-230.

Ansell, Ben W., From the Ballot to the Blackboard. The Redistributive Political Economy of Education (Cambridge: Cambridge University Press, 2010).

Archer, Margaret S., Social Origins of Educational Systems (London: Sage Publications, 1979).

Archer, Margaret S., Social Origins of Educational Systems, university edition (London: Sage Publications, 1984).

Archer, Margaret S., 'Cross-National Research and the Analysis of Educational Systems', in Melvin L. Kohn, ed., Cross-National Research in Sociology (Newbury Park, Calif.: Sage Publications, 1989), pp. 243-62.

Arts, Wil, and John Gelissen, 'Welfare States, Solidarity and Justice Principles: Does the Type Really Matter?', Acta Sociologica, 44 (2001), 283-99.

Ashton, David, and Francis Green, Education, Training and the Global Economy (Cheltenham, Gloucs.: Edward Elgar, 1996).

Ball, Stephen J., 'Education Markets, Choice and Social Class: The Market as a Class Strategy in the UK and the USA', British Journal of Sociology and Education, 14 (1993), 3-19.

Balzer, Caroline, and Alessandra Rusconi, 'From the European Commission to the Member States and Back - A Comparison of the Bologna and the Copenhagen Process', in Kerstin Martens, Alessandra Rusconi and Kathrin Leuze, eds, New Arenas of Education Governance: The Impact of International Organizations and Markets on Educational Policy Making (Basingstoke, Hants.: Palgrave Macmillan, 2007), pp. 57-75.

Barro, Robert J., 'Human Capital and Growth', American Economic Review, Papers and Proceedings, 91 no. 2 (2001), 12-7.

Baum, Matthew A., and David A. Lake, 'The Political Economy of Growth: Democracy and Human Capital', American Journal of Political Science, 47 (2003), 333-47.

Becher, Tony, and Maurice Kogan, Process and Structure in Higher Education (London: Routledge, 1992).

Becker, Uwe, 'Open Systemness and Contested Reference Frames and Change: A Reformulation of the Varieties of Capitalism Theory', Socio-Economic Review, 5 (2007), 261-86.

Bleiklie, Ivar, and Maurice Kogan, 'Comparison and Theories', in Maurice Kogan, Marianne Bauer, Ivar Bleiklie and Mary Henkel, eds, Transforming Higher Education: A Comparative Study (Dordrecht: Springer, 2006), pp. 3-22.

Blossfeld, Hans-Peter, 'Is the German Dual System a Model for a Modern Vocational Training System?', International Journal of Comparative Sociology, 33 (1992), 168-81.

Boix, Carles, 'Political Parties and the Supply Side of the Economy: The Provision of Physical and Human Capital in Advanced Economies, 1960-1990', American Journal of Political Science, 41 (1997), 814-45.

Boix, Carles, Political Parties, Growth and Equality: Conservative and Social Democratic Economic Strategies in the World Economy (Cambridge: Cambridge University Press, 1998). 
Borrás, Susana, 'The Politics of the Lisbon Strategy: The Changing Role of the Commission', West European Politics, 32 (2009), 97-118.

Bosch, Gerhard, and Jean Charest, 'Vocational Training and the Labour Market in Liberal and Coordinated Market Economies', Industrial Relations Journal, 39 (2008), 428-47.

Bosch, Gerhard, and Jean Charest, eds, Vocational Training: International Perspectives (Abingdon, Oxon.: Routledge, 2010).

Bourdieu, Pierre, Distinction: A Social Critique of the Judgements of Taste (Cambridge, Mass.: Harvard University Press, 1984).

Bowles, Samuel, and Herbert Gintis, 'Does Schooling Raise Earnings by Making People Smarter?', in Kenneth Arrow, Samuel Bowles and Steven Durlauf, eds, Meritocracy and Economic Inequality (Princeton, N.J.: Princeton University Press, 2000), pp. 118-36.

Braun, Dietmar, and François-Xavier Merrien, eds, Towards a New Model of Governance for Universities? A Comparative View (London: Jessica Kingsley, 1999).

Bray, Mark, Bob Adamson, and Mark Mason, Comparative Education Research: Approaches and Methods (Comparative Education Research Centre: University of Hong Kong, 2007).

Brockmann, Michaela, Linda Clarke, and Christopher Winch, 'Knowledge, Skills, and Competence: European Divergences in Vocational Education and Training (VET) - the English, German, and Dutch Cases', Oxford Review of Education, 34 (2008), 547-67.

Brown, David S., and Wendy Hunter, 'Democracy and Human Capital Formation', Comparative Political Studies, 37 (2004), 842-64.

Brown, Philipp, 'Skill Formation in the Twenty-First Century', in Philipp Brown, Andy Green and Hugh Lauder, eds, High Skills: Globalization, Competitiveness, and Skill Formation (Oxford: Oxford University Press, 2001), pp. 1-55.

Burtless, Gary, ed., Does Money Matter? The Effect of School Resources on Student Achievement and Adult Success (Washington, D.C.: The Brookings Institution, 1996).

Busemeyer, Marius R., 'The Determinants of Public Education Spending in 21 OECD Democracies, 1980-2001', Journal of European Public Policy, 14 (2007), 582-610.

Busemeyer, Marius R., 'The Impact of Fiscal Decentralization on Education and Other Types of Spending', Swiss Political Science Review, 14 (2008), 451-81.

Busemeyer, Marius R., 'Asset Specificity, Institutional Complementarities and the Variety of Skill Regimes in Coordinated Market Economies', Socio-Economic Review, 7 (2009a), 375-406.

Busemeyer, Marius R., 'Social Democrats and the New Partisan Politics of Public Investment in Education', Journal of European Public Policy, 16 (2009b), 107-26.

Busemeyer, Marius R., 'Redistribution and the Political Economy of Education: An Analysis of Individual Preferences in OECD Countries' (CES Working Paper, University of Harvard, 2010).

Busemeyer, Marius R., Achim Goerres, and Simon Weschle, 'Attitudes Towards Redistributive Spending in an Era of Demographic Ageing: The Rival Pressures from Age and Income in 14 OECD Countries', Journal of European Social Policy, 19 (2009), 195-212.

Busemeyer, Marius R., and Rita Nikolai, 'Education', in Francis G. Castles, Jane Lewis, Herbert Obinger, Chris Pierson and Stephan Leibfried, eds, The Oxford Handbook on Welfare State Policy (Oxford: Oxford University Press, 2010), pp. 494-508.

Busemeyer, Marius R., and Christine Trampusch, eds, The Comparative Political Economy of Collective Skill Formation Systems (Oxford: Oxford University Press, forthcoming 2011).

Castles, Francis G., 'The Impact of Parties on Public Expenditure', in Francis G. Castles, ed., The Impact of Parties: Politics and Policies in Democratic Capitalist States (London: Sage Publications, 1982), pp. 21-96.

Castles, Francis G., 'Explaining Public Education Expenditure in OECD Nations', European Journal of Political Research, 17 (1989), 431-8.

Castles, Francis G., Comparative Public Policy: Patterns of Post-War Transformation (Cheltenham, Gloucs. Edward Elgar, 1998).

Chubb, John E., and Terry M. Moe, Politics, Markets, and America's Schools (Washington, D.C.: The Brookings Institution, 1990). 
Clark, Burton R., The Higher Education System: Academic Organization in Cross-National Perspective (Berkeley: University of California Press, 1983).

Clarke, Linda, and Christopher Winch, 'A European Skills Framework? But What Are Skills? Anglo-Saxon versus German Concepts', Journal of Education and Work, 19 (2006), 255-69.

Clarke, Linda, and Christopher Winch, eds, Vocational Training: International Approaches, Developments and Systems (London: Routledge, 2007).

Clune, William H., and John F. Witte, Choice and Control in American Education: Vol. 2, The Practice of Choice, Decentralization and School Restructuring (Basingstoke, Hants.: Falmer Press, 1990).

Collins, Randall, The Credential Society: An Historical Sociology of Education and Stratification (New York: Academic Press, 1979).

Crouch, Colin, and Wolfgang Streeck, eds, Political Economy of Modern Capitalism (London: Sage, 1997).

Crouch, Colin, David Finegold, and Mari Sako, Are Skills the Answer? The Political Economy of Skill Creation in Advanced Industrial Countries (Oxford: Oxford University Press, 1999).

Culpepper, Pepper D., Creating Cooperation: How States Develop Human Capital in Europe (Ithaca, N.Y.: Cornell University Press, 2003).

Culpepper, Pepper D., 'Small States and Skill Specificity: Austria, Switzerland, and Interemployer Cleavages in Coordinated Capitalism', Comparative Political Studies, 40 (2007), 611-37.

Culpepper, Pepper D., and David Finegold, eds, The German Skills Machine: Sustaining Comparative Advantage in a Global Economy (New York: Berghahn Books, 1999).

Culpepper, Pepper D., and Kathleen Thelen, 'Institutions and Collective Actors in the Provision of Training: Historical and Cross-National Comparisons', in Karl Ulrich Mayer and Heike Solga, eds, Skill Formation: Interdisciplinary and Cross-National Perspectives (Cambridge: Cambridge University Press, 2008), pp. 21-49.

Cusack, Thomas, Torben Iversen, and Philipp Rehm, 'Risks at Work: The Demand and Supply Sides of Government Redistribution', Oxford Review of Economic Policy, 22 (2006), 365-89.

Cusack, Thomas R., Torben Iversen, and David Soskice, 'Economic Interests and the Origins of Electoral Systems', American Political Science Review, 101 (2007), 373-91.

de Ruiter, Rik, 'Multilateral Surveillance in Education by OMC', In Anja P. Jakobi, Kerstin Martens and Klaus Dieter Wolf, eds, Education in Political Science: Discovering a Neglected Field (London: Routledge, ECPR Studies in European Political Science, 2009), pp. 140-55.

De Swaan, Abram, In Care of the State: Health Care, Education and Welfare in Europe and the USA in the Modern Era (Cambridge: Polity Press, 1988).

Dobbins, Michael, and Christoph Knill, 'Higher Education Policies in Central and Eastern Europe, Convergence Toward a Common Model?', Governance, 22 (2009), 397-430.

Dronkers, Jaap, and Peter Robert, 'School Choice in the Light of the Effectiveness Differences of Various Types of Public and Private Schools in 19 OECD Countries', Journal of School Choice, 2 (2008), 260-301.

Emmenegger, Patrick, 'Specificity versus Replaceability: The Relationship between Skills and Preferences for Job Security Regulations', Socio-Economic Review, 7 (2009), 407-30.

Enders, Jürgen, 'Higher Education, Internationalization, and the Nation-State: Recent Developments and Challenges to Governance Theory', Higher Education, 47 (2004), 361-82.

Ertl, Hubert, 'The European Union and Education and Training: An Overview of Policies and Initiatives', in David Phillips and Hubert Ertl, eds, Implementing European Union Education and Training Policy: A Comparative Study of Issues in Four Member States (Dordrecht: Kluwer Academic, 2003), pp. 13-39.

Ertl, Hubert, 'European Union Policies in Education and Training: The Lisbon Agenda as a Turning Point?', Comparative Education, 42 (2006), 5-27.

Esping-Andersen, Gøsta, The Three Worlds of Welfare Capitalism (Cambridge: Polity Press, 1990).

Estévez-Abe, Margarita, Torben Iversen, and David Soskice, 'Social Protection and the Formation of Skills: A Reinterpretation of the Welfare State', in Peter A. Hall and David Soskice, eds, 
Varieties of Capitalism: The Institutional Foundations of Comparative Advantage (Oxford: Oxford University Press, 2001), pp. 145-83.

Feinstein, Leon, 'Quantitative Estimates of the Social Benefits of Learning: 2: Health (Depression and Obesity)' (London: Centre for Research on the Wider Benefits of Learning Research Report No. 6, October 2002).

Finegold, David, and David Soskice, 'The Failure of Training in Britain: Analysis and Prescription', Oxford Review of Economic Policy, 4 (1988), 21-53.

Flude, Mike, and Sandy Sieminksi, eds, Education, Training and the Future of Work II: Developments in Vocational Education and Training (London: Routledge, 1999).

Franz, Wolfgang, and David Soskice, 'The German Apprenticeship System', in Friedrich Buttler et al., eds, Institutional Frameworks and Labor Market Performance: Comparative Views on the U.S. and German Economies (London: Routledge, 1995), pp. 208-34.

Gamoran, Adam, and Robert D. Mare, 'Secondary School Tracking and Educational Inequality: Compensation, Reinforcement, or Neutrality?', American Journal of Sociology, 94 (1989), 1146-83.

Goedegebuure, Leo, Frans Kaiser, and Peter Massen, et al, eds, Higher Education Policy: An International Comparative Perspective (Oxford: Pergamon Press, 1994).

Goldthorpe, John H., On Sociology: Numbers, Narratives, and the Integration of Research and Theory (New York: Oxford University Press, 2000).

Gornitzka, Ase, 'The Open Method of Coordination as Practice - A Watershed in European Education Policy', (University of Oslo Arena Centre for European Studies, Working Paper 16, 2006).

Green, Andy, Education and State Formation: The Rise of Education Systems in England, France and the USA (Houndmills, Hants.: Macmillan, 1990).

Green, Andy, 'Models of High Skills in National Competition Strategies', in Philipp Brown, Andy Green and Hugh Lauder, eds, High Skills: Globalization, Competitiveness, and Skill Formation (Oxford: Oxford University Press, 2001), pp. 56-160.

Green, Andy, Jan Germen Janmaat, and John Preston, Education, Equality and Social Cohesion: A Comparative Analysis (Basingstoke, Hants: Palgrave Macmillan, 2006).

Hall, Peter A., and David Soskice, 'An Introduction to Varieties of Capitalism', in Peter A. Hall and David Soskice, eds, Varieties of Capitalism: The Institutional Foundations of Comparative Advantage (Oxford: Oxford University Press, 2001), pp. 1-68.

Hanushek, Eric A., 'The Economics of Schooling: Production and Efficiency in Public Schools', Journal of Economic Literature, 24 (1986), 1141-77.

Hanushek, Eric A., and Dennis D. Kimko, 'Schooling, Labor-Force Quality, and the Growth of Nations', American Economic Review, 90 (2000), 1184-208.

Hanushek, Eric A., and L. Wössmann, 'Does Educational Tracking Affect Performance and Inequality? Differences-In-Differences Evidence Across Countries' (SIEPR Discussion Paper 2004 , no. 26 (2005)).

Hanushek, Eric A., and Ludger Woessmann, 'The Role of Cognitive Skills in Economic Development', Journal of Economic Literature, 46 (2008), 607-68.

Hega, Gunther M., and Karl G. Hokenmaier, 'The Welfare State and Education: A Comparison of Social and Educational Policy in Advanced Industrial Societies', German Policy Studies, 2 (2002), 143-73.

Heidenheimer, Arnold J., 'The Politics of Public Education, Health and Welfare in the USA and Western Europe: How Growth and Reform Potentials Have Differed', British Journal of Political Science, 3 (1973), 315-40.

Heidenheimer, Arnold J., 'Education and Social Security Entitlements in Europe and America', in Peter Flora and Arnold J. Heidenheimer, eds, The Development of Welfare States in Europe and America (New Brunswick, N.J.: Transaction Books, 1981), pp. 269-304.

Heidenheimer, Arnold J., 'Throwing Money and Heaving Bodies: Heuristic Callisthenics for Comparative Policy Buffs', in Louis M. Imbeau and Robert D. McKinlay, eds, Comparing Government Activity (New York: St. Martin's, 1996), pp. 13-25. 
Heidenheimer, Arnold J., Disparate Ladders: Why School and University Policies Differ in Germany, Japan, and Switzerland (New Brunswick, N.J.: Transaction Books, 1997).

Heidenheimer, Arnold J., Hugh Heclo, and Carolyn Teich Adams, Comparative Public policy: The Politics of Social Choice in America, Europe, and Japan (New York: St. Martin's, 1990).

Helliwell, John F., and Robert D. Putnam, 'Education and Social Capital' (NBER Working Papers, no. 7121, 1999), available at http://www.nber.org/papers/w7121.

Hollingsworth, J. Rogers, and Robert J. Boyer, eds, Contemporary Capitalism (Cambridge: Cambridge University Press, 1997).

Howell, Chris, 'Varieties of Capitalism: And Then There was One?', Comparative Politics, 36 (2003), 103-24.

Huber, Evelyne, and John D. Stephens, Development and Crisis of the Welfare State: Parties and Policies in Global Markets (Chicago: University of Chicago Press, 2001).

Huo, Jinging, 'The Role of Interfirm Networks in Technological Innovation and Education', Comparative Political Studies, 42 (2009), 587-610.

Iversen, Torben, Capitalism, Democracy, and Welfare (Cambridge: Cambridge University Press, 2005).

Iversen, Torben, and David Soskice, 'An Asset Theory of Social Policy Preferences', American Political Science Review, 95 (2001), 875-93.

Iversen, Torben, and David Soskice, 'Distribution and Redistribution: The Shadow of the Nineteenth Century', World Politics, 61 (2009), 438-86.

Iversen, Torben, and John D. Stephens, 'Partisan Politics, the Welfare State, and Three Worlds of Human Capital Formation', Comparative Political Studies, 41 (2008), 600-37.

Jackson, Gregory, and Richard Deeg, 'How Many Varieties of Capitalism? Comparing the Comparative Institutional Analyses of Capitalist Diversity' (MPIfG Disucssion Paper, 6, no. 2, 2006).

Jakobi, Anja P., 'International Organizations and Policy-Diffusion. The Global Norm of Lifelong Learning' (paper presented at the ECPR Joint Sessions, Lisbon, Workshop 10, 2009).

Jakobi, Anja P., and Kerstin Martens, 'Diffusion durch Internationale Organisationen: Die Bildungspolitik der OECD', in Katharina. Holzinger, Helge Jörgens and Christoph Knill, eds, Transfer, Diffusion und Konvergenz von Politiken (Politische Vierteljahresschrift, Sonderheft no. 38, 2007), pp. 247-70.

Jakobi, Anja P., Kerstin Martens, and Klaus Dieter Wolf, eds, Education in Political Science: Discovering a Neglected Field (London: Routledge, 2009a).

Jakobi, Anja P., Kerstin. Martens, and Klaus Dieter Wolf, 'Introduction', in Anja P. Jakobi, Kerstin Martens and Klaus Dieter Wolf, eds, Education in Political Science. Discovering a Neglected Field (London: Routledge, ECPR Studies in European Political Science, 2009b), pp. 1-20.

Jensen, Carsten, 'Capitalist Systems, De-Industrialization, and the Politics of Education', Comparative Political Studies (forthcoming 2011).

Keeling, Ruth, 'The Bologna Process and the Lisbon Research Agenda: The European Commission's Expanding Role in Higher Education Discourse', European Journal of Education, 41 (2006), 203-23.

Kitschelt, Herbert, 'Collective Group Interests and Distributive Outcomes: Competing Claims about the Evolution of the Welfare State', Labor History, 47 (2006), 411-20.

Kitschelt, Herbert, Peter Lange, Gary Marks, and John D. Stephens, eds, Continuity and Change in Contemporary Capitalism (Cambridge: Cambridge University Press, 1999).

Klitgaard, Michael Baggesen, 'Do Welfare State Regimes Determine Public Sector Reforms? Choice Reforms in American, Swedish and German Schools', Scandinavian Political Studies, 30 (2007), 444-68.

Klitgaard, Michael Baggesen, 'School Vouchers and the New Politics of the Welfare State', Governance, 21 (2008), 479-98.

Kogan, Maurice, Marianne Bauer, Ivar Bleiklie, and Mary Henkel, eds, Transforming Higher Education: A Comparative Study (Dordrecht: Springer, 2006). 
Korpi, Walter, 'Power Resources and Employer-Centered Approaches in Explanations of Welfare States and Varieties of Capitalism: Protagonists, Consenters, and Antagonists', World Politics, 58 (2006), 167-206.

Kupfer, Antonia, 'Policies of Differentiation in Higher Education in Britain and in Germany: Effects on Social Recruitment' (paper presented at the ECPR Joint Sessions, Lisbon, Workshop 10, 2009).

Lee, Cheol-Sung, 'Why Do Some Employees Support Welfare States More Than Others? Skill Profiles and Social Policy Preferences in the United States', Social Science Research, 36 (2007), 688-718.

Leuze, Kathrin et al., 'Analysing the Two-Level Game: International and National Determinants of Change in Education Policy Making' (University of Bremen, Transformations of the State CRC 597, Working Paper No. 72, 2008).

Lindert, Peter, Growing Public: Social Spending and Economic Growth Since the Eighteenth Century (Cambridge: Cambridge University Press, 2004).

Lochner, Lance, and Enrico Moretti, 'The Effect of Education on Crime: Evidence from Prison Inmates, Arrests, and Self-Reports', American Economic Review, 94 (2004), 155-89.

Lundahl, Lisbeth, 'Sweden: Decentralisation, Deregulation, Quasi-Markets - And Then What?', Journal of Education Policy, 17 (2002), 687-97.

Mahoney, James, 'After KKV: The New Methodology of Qualitative Research', World Politics, 62 (2010), 120-47.

Mares, Isabela, The Politics of Social Risk: Business and Welfare State Development (Cambridge: Cambridge University Press, 2003).

Martens, Kerstin, and Klaus Dieter Wolf, 'Paradoxien der neuen Staatsräson. Die Internationalisierung der Bildungspolitik in der EU und der OECD', Zeitschrift für Internationale Beziehungen, 13 (2006), 145-76.

Martin, Cathie Jo, Stuck in Neutral: Business and the Politics of Human Capital Investment Policy (Princeton, N.J.: Princeton University Press, 2000).

Martin, Cathie Jo, and Duane Swank, 'The Political Origins of Coordinated Capitalism: Business Organizations Party Systems and State Structure in the Age of Innocence', American Political Science Review, 102 (2008), 181-98.

Mosher, James S., 'U.S. Wage Inequality, Technological Change, and Decline in Union Power', Politics \& Society, 35 (2007), 225-64.

Musselin, Christine, 'State/University Relations and How to Change Them: The Case of France and Germany', European Journal of Education, 32 (1997), 145-64.

Nagel, Alexander, 'Education Policy Networks in the Bologna Process', in Anja P. Jakobi, Kerstin Martens and Klaus Dieter Wolf, eds, Education in Political Science. Discovering a Neglected Field (London: Routledge ECPR Studies in European Political Science, 2009).

Nelson, Moira, 'Education Policy and the Consequences for Labor Market Integration in Denmark, Germany, and the Netherlands' (doctoral dissertation, University of North Carolina at Chapel Hill, Department of Political Science, 2008).

Nickell, Stephen, 'Poverty and Worklessness, in Britain', Economic Journal, 114 (2004), C1-25.

OECD, Education at a Glance 2008: OECD Indicators (Paris: Organisation for Economic Co-operation and Development, 2008).

Pépin, Luce, 'The History of EU Cooperation in the Field of Education and Training: How Lifelong Learning Became a Strategic Objective', European Journal of Education, 42 (2007), 121-32.

Pierson, Paul, 'Increasing Returns, Path Dependency, and the Study of Politics', American Political Science Review, 94 (2000), 251-67.

Pierson, Paul, ed., The New Politics of the Welfare State (Oxford: Oxford University Press, 2001).

Pierson, Paul, Politics in Time: History, Institutions, and Social Analysis (Princeton, N.J.: Princeton University Press, 2004). 
Poterba, James, 'Demographic Structure and the Political Economy of Public Education', Journal of Public Policy and Management, 16 (January 1997), 48-66.

Powell, Justin W., and Heike Solga, 'Internationalization of Vocational and Higher Education Systems - A Comparative-Institutional Approach' (Social Science Research Center Berlin (WZB) Discussion Paper SP I 2008-501, 2008).

Ringer, Fritz K., Education and Society in Modern Europe (Bloomington: Indiana University Press, 1979).

Rouse, Cecilia Elena, and Lisa Barrow, 'School Vouchers and Students Achievements: Recent Evidence and Remaining Questions', Annual Review of Economics, 1 (2009), 17-42.

Scharpf, Fritz W., 'Institutions in Comparative Policy Research', Comparative Political Studies, 33 (2000), 762-90, at pp. 762-3.

Scherrer, Christoph, 'GATS: Long-term Strategy for the Commodification of Education', Review of International Political Economy, 12 (2005), 484-510.

Scherrer, Christoph, 'GATS - Commodifying Education via Trade Treaties', in Kerstin Martens, Alessandra Rusconi and Kathrin Leuze, eds, New Arenas of Education Governance: The Impact of International Organizations and Markets on Educational Policy Making (Basingstoke, Hants.: Palgrave Macmillan, 2007), pp. 117-35.

Schlicht, Raphaela, Isabelle Stadelmann-Steffen, and Markus Freitag, 'Educational Inequality in the EU: The Effectiveness of the National Education Systems', European Union Politics, 11 (2010), 29-59.

Schmidt, Manfred G., 'When Parties Matter: A Review of the Possibilities and Limits of Partisan Influence on Public Policy', European Journal of Political Research, 30 (1996), 155-83.

Schmidt, Manfred G., 'Testing the Retrenchment Hypothesis: Educational Spending, 1960-2002', in Francis G. Castles, ed., The Disappearing State? Retrenchment Realities in an Age of Globalisation (Cheltenham, Gloucs: Elgar, 2007), pp. 159-83.

Schuetz, Gabriela, Heinrich W. Ursprung, and Ludger Woessmann, 'Education Policy and Equality of Opportunity' (IZA DP, no. 1906, December 2005).

Soskice, David, 'Reconciling Markets and Institutions: The German Apprenticeship System', in Lisa M. Lynch, ed., Training and the Private Sector: International Comparisons (Chicago: University of Chicago Press, 1994), pp. 25-60.

Soskice, David, 'Divergent Production Regimes: Coordinated und uncoordinated market economies in the 1980s and 1990s', in Herbert Kitschelt et al., eds, Continuity and Change in Contemporary Capitalism (Cambridge: Cambridge University Press, 1999), pp. 101-34.

Stasavage, David, 'Democracy and Education Spending in Africa', American Journal of Political Science, 49 (2005), 343-58.

Stephens, John D., 'Partisan Government, Employers' Interests, and the Welfare State', Labour History, 47 (2006), 420-9.

Stevens, Mitchell L., Elizabeth A. Armstrong, and Richard Arum, 'Sieve, Incubator, Temple, Hub: Empirical and Theoretical Advances in the Sociology of Higher Education', Annual Review of Sociology, 34 (2008), 127-51.

Streeck, Wolfgang, 'Skills and the Limits of Neo-Liberalism: The Enterprise of the Future as a Place of Learning', Work, Employment \& Society, 3 (1989), 89-104.

Streeck, Wolfgang, Social Institutions and Economic Performance: Studies of Industrial Relations in Advanced Capitalist Economies (London: Sage, 1992).

Streeck, Wolfgang, 'Educating Capitalists: A Rejoinder to Wright and Tsakalotos', Socio-Economic Review, 2 (2004), 425-38.

Streeck, Wolfgang, Re-Forming Capitalism: Institutional Change in the German Political Economy (Oxford: Oxford University Press, 2009).

Streeck, Wolfgang, and Philippe C. Schmitter, 'Community, Market, State - and Associations? The Prospective Contribution of Interest Governance to Social Order', in Wolfgang Streeck and Philippe C. Schmitter, eds, Private Interest Government: Beyond Market and State (London: Sage, 1985), pp. 1-29. 
Streeck, Wolfgang, and Kathleen Thelen, 'Introduction: Institutional Change in Advanced Political Economies', In Wolfgang Streeck and Kathleen Thelen, eds, Beyond Continuity: Institutional Change in Advanced Political Economies (Oxford: Oxford University Press, 2005), pp. 1-39.

Svallfors, Stefan, 'Welfare Regimes and Welfare Opinions: a Comparison of Eight Western Countries', Social Indicators Research, 64 (2003), 495-520.

Swenson, Peter A., Capitalists against Markets: The Making of Labor Markets and Welfare States in the United States and Sweden (Oxford: Oxford University Press, 2002).

Tepe, Markus, and Pieter Vanhuysse, 'Are Aging Welfare States on the Path to the Politics of Gerontocracy? Evidence from 18 Democracies, 1980-2002', Journal of Public Policy, 29 (2009), 1-28.

Thelen, Kathleen, 'How Institutions Evolve', in James Mahoney and Dietrich Rueschemeyer, eds, Comparative Historical Analysis in the Social Sciences (Cambridge: Cambridge University Press, 2003), pp. 208-40.

Thelen, Kathleen, How Institutions Evolve: The Political Economy of Skills in Germany, Britain, the United States and Japan (Cambridge: Cambridge University Press, 2004).

Thelen, Kathleen, 'Skill Formation and Training', in Geoffrey Jones and Jonathan Zeitlin, eds, The Oxford Handbook of Business History (Oxford: Oxford University Press, 2007), pp. $558-80$.

Thelen, Kathleen, and Marius R. Busemeyer 'From Collectivism towards Segmentalism: Institutional Change in German Vocational Training' (MPIfG Discussion, 8, no. 13 (2008)).

Thelen, Kathleen, and Ikuo Kume, 'The Rise of Nonmarket Training Regimes: Germany and Japan Compared', Journal of Japanese Studies, 25 (1999), 33-4.

Toner, Phillip, 'Survival and Decline of the Apprenticeship System in the Australian and UK Construction Industries', British Journal of Industrial Relations, 46 (2008), 413-38.

Trampusch, Christine, 'Jenseits von Anpassungsdruck und Lernen - Die EU-Berufsbildungspolitik und die Europäisierung der deutschen Berufsbildungspolitik', Zeitschrift für Staats- und Europawissenschaften, 6 (2008), 577-605.

Trampusch, Christine, 'Europeanization and Institutional Change in Vocational Education and Training in Germany and Austria', Governance: An International Journal of Policy, Administration and Institutions, 22 (2009), 371-97.

Trampusch, Christine, 'Co-evolution of Skills and Welfare in Coordinated Market Economies? A Comparative Historical Analysis of Denmark, the Netherlands, and Switzerland', European Journal of Industrial Relations, 16 no. 3 (2010a), 197-220.

Trampusch, Christine, 'Employers, the State, and the Politics of Institutional Change: Vocational Education and Training in Austria, Germany and Switzerland', European Journal of Political Research, 49 (2010b), 545-73.

Van Vught, Frans A. ed., Governmental Strategies and Innovation in Higher Education (London: Jessica Kingsley, 1989).

Verger, Antoni, 'State Actors and Preferences in Education in the Context of GATS', in Anja P. Jakobi, Kerstin Martens and Klaus Dieter Wolf, eds, Education in Political Science: Discovering a Neglected Field (London: Routledge, ECPR Studies in European Political Science, 2009), pp. 123-39.

Verner, Joel G., 'Socioeconomic Environment, Political System, and Educational Policy Outcomes: A Comparative Analysis of 102 Countries', Comparative Politics, 11 no. 2 (1979), 165-87.

Walkenhorst, Horst, 'Explaining Change in EU Education Policy', Journal of European Public Policy, 15 (2008), 567-87.

Weaver, Kent R., and Bert A. Rockmann, eds, Do Institutions Matter? Government Capabilities in the United States and Abroad (Washington, D.C.: The Brookings Institution, 1993).

West, Anne, Jutta Allmendinger, and Rita Nikolai, 'Decentralisation and Educational Achievement in Germany', Environment and Planning C: Government and Policy, 28 (2010), 450-68.

Windolf, Paul, Expansion and Structural Change: Higher Education in Germany, United States and Japan 1870-1990 (Boulder, Colo.: Westview, 1997). 
Witte, Johanna, Change of Degrees and Degrees of Change: Comparing Adaptations of European Higher Education Systems in the Context of the Bologna Process (Entschede: CHEOS/ Universiteit Twente, 2006).

Wolf, Frieder, 'The Division of Labour in Education Funding: A Cross-National Comparison of Public and Private Education Expenditure in 28 OECD Countries', Acta Politica, 44 (2009), 50-73.

Wolf, Frieder, and Reimut Zohlnhöfer, 'Investing in Human Capital? The Determinants of Private Education Expenditure in 26 OECD Countries', Journal of European Social Policy, 19 (2009), 230-44.

Wolter, Stefan, and Alejandrea M. Cattaneo, 'Are the Elderly a Threat to Educational Expenditures?', European Journal of Political Economy, 25 (2009), 225-36.

Wössmann, Ludger, 'International Evidence on School Competition, Autonomy, and Accountability: A Review', Peabody Journal of Education, 82 (2007), 473-97. 